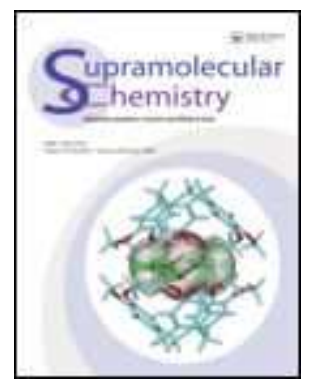

\title{
CONFORMATIONALLY MOBILE GLUCOSYLTHIOUREIDO- CALIX[6]- AND CALIX[8]ARENES: SYNTHESIS, AGGREGATION AND LECTIN BINDING
}

\begin{tabular}{|c|c|}
\hline Journal: & Supramolecular Chemistry \\
\hline Manuscript ID: & GSCH-2007-0124.R1 \\
\hline Manuscript Type: & Special Issue Paper \\
\hline $\begin{array}{l}\text { Date Submitted by the } \\
\text { Author: }\end{array}$ & 26-Oct-2007 \\
\hline Complete List of Authors: & $\begin{array}{l}\text { Sansone, Francesco; Università di Parma, Dipartimento di Chimica } \\
\text { Organica e Industriale } \\
\text { Baldini, Laura; Università di Parma, Dipartimento di Chimica } \\
\text { Organica e Industriale } \\
\text { Casnati, Alessandro; Università di Parma, Dipartimento di Chimica } \\
\text { Organica e Industriale } \\
\text { Ungaro, Rocco; Università di Parma, Dipartimento di Chimica } \\
\text { Organica e Industriale }\end{array}$ \\
\hline Keywords: & $\begin{array}{l}\text { glycocalixarenes, multivalent systems, lectins, AFM, self- } \\
\text { aggregation }\end{array}$ \\
\hline
\end{tabular}

\section{$\diamond$ ScholarONE" \\ Manuscript Central}




\title{
CONFORMATIONALLY MOBILE GLUCOSYLTHIOUREIDO-
}

\section{CALIX[6]- AND CALIX[8]ARENES: SYNTHESIS, AGGREGATION \\ AND LECTIN BINDING}

Francesco Sansone, Laura Baldini, Alessandro Casnati,* Rocco Ungaro

Dipartimento di Chimica Organica e Industriale, Università degli Studi, V.le G.P. Usberti 17/A, 43100 Parma, Italy

francesco.sansone@unipr.it

alessandro.casnati@unipr.it

laura.baldini@unipr.it

rocco.ungaro@unipr.it

\begin{abstract}
Two new glucoclusters $\mathbf{2 a}$ and $\mathbf{2} \mathbf{b}$, in which the sugar units are connected to the upper rim of methoxycalix[6]- and calix[8]arene derivatives via thiourea linkages, were synthesized and their aggregation properties in water studied by ${ }^{1} \mathrm{H}$ NMR, Atomic Force Microscopy (AFM) and Dynamic Light Scattering (DLS). Small size aggregates (2-10 $\mathrm{nm}$ diameter) are formed by both macrocycles, which become much larger (200-300 $\mathrm{nm})$ in the presence of a phosphate buffer, whereas other anions $\left(\mathrm{Cl}^{-}, \mathrm{NO}_{3}{ }^{-}, \mathrm{SO}_{4}{ }^{-}\right)$have no effect.
\end{abstract}


The glycoclusters $\mathbf{2 a}$ and $\mathbf{2 b}$ interact with plasmid DNA but do not condense it, while in the presence of a glucose specific lectin such as Concanavalin A (ConA) agglutination occurs. The data obtained give useful insight into the mode of binding of calixarenebased glycoclusters with lectins.

Keywords glycocalixarenes, multivalent systems, lectins, AFM, self-aggregation

Dedicated to David N. Reinhoudt for his outstanding contributions to Supramolecular Chemistry and Nanotechnology

\section{Introduction}

The fundamental role played by carbohydrates in many biological processes [1-8] and the phenomenon of multivalency $[9,10]$ frequently associated with the recognition of these substrates have boosted the design and synthesis of a wide range of polyglycosylated compounds [11-17]. The major aim is to clarify the principles $[10,18]$ of the so-called glycoside cluster effect [19] and find new bioactive molecules for diagnostic [20] and therapy [21-23] based on the saccharide recognition.

Since several years we have been engaged in the synthesis of calixarene-based multivalent glycoclusters [24] and proved their ability of binding to specific lectins [25] and toxins [26]. Although the multivalent presentation of the saccharide units seems to play a positive role in the recognition process, the real mode of binding of these derivatives has not been clarified yet. Recent reports on calixarene glycoclusters having long alkyl chains at the lower rim have shown [27,28] that they can self-aggregate in 
water giving small micelle-like nanoparticles in which the real valency at work could be much higher compared to that of the monomeric species.

We present here the synthesis and supramolecular properties of two new, water soluble glycocalixarenes having different size and characterised by the presence of glucose at the upper rim and methyl groups at the lower rim. Among the neutral monosaccharides glucose was chosen because of its high solubility in water and also for its biological relevance in the perspective of using these molecules as selective molecular delivery systems. Many glucose transporters are in fact present at the blood brain barrier which are considered as possible targets for increasing brain access to drug molecules [29]. The thiourea unit, frequently used by us to link the carbohydrate unit to the calixarene platform, can also act as hydrogen bonding donor group and influence the supramolecular properties of the glycoclusters.

\section{Results and discussion}

Using the well established procedure involving amine and isothiocyanate units to form thiourea groups, the condensation between the proper aminocalix[n]arenes [30] and tetraacetyl- $\beta$-L-glucosylisothiocyanate (Scheme 1) afforded the protected glucocalixarenes $\mathbf{1 a}$ and $\mathbf{1 b}$, whose acetyl groups were subsequently removed by the Zemplen method (NaOMe in methanol).

\section{[Insert Scheme 1]}

The ${ }^{1} \mathrm{H}$ NMR spectra of the protected compounds $\mathbf{1 a}$ and $\mathbf{1 b}$ in $\mathrm{CDCl}_{3}$, where hydrogen bonding is possible, are characterised by broad signals which indicate a restricted 
mobility of the phenolic units and a slow exchange between the isomers of the thiourea units typical for the disubstituted thioureas, including thioureidoglycosides [25]. In more polar solvents like $\mathrm{CD}_{3} \mathrm{OD}$ and DMSO- $d_{6}$, which break hydrogen bonding, the signals are fairly sharp and become even sharper by increasing the temperature, as shown in Fig. 1 for the octamer $\mathbf{1 b .}$

\section{[Insert Figure 1]}

The deprotected glucoclusters $\mathbf{2 a}$ and $\mathbf{2 b}$ resulted soluble in water up to $5 \times 10^{-3} \mathrm{M}$ by sonication, but the solutions of both become rapidly heterogeneous and a significant precipitation of a white solid occurs after few minutes. More stable solutions are obtained at a concentration of $10^{-4}$ and $10^{-3} \mathrm{M}$ for the calix[6]- and calix[8]arene derivatives, respectively. Also the ${ }^{1} \mathrm{H}$ NMR spectra of aqueous solutions of both calixarenes show quite broad signals at room temperature (Fig. 2a) which are indeed sharper at $363 \mathrm{~K}$ (Fig. 2b), thus suggesting the formation of self-assembled aggregates in equilibrium with the monomeric macrocycle.

\section{[Insert Figure 2]}

To shed more light on this phenomenon, we performed Atomic Force Microscopy (AFM) experiments in tapping mode on freshly cleaved mica surfaces with $5 \times 10^{-4} \mathrm{M}$ water solutions of the two glucoclusters. The results confirmed the tendency for the calix[6]- 2a and calix[8]arene $\mathbf{2 b}$ to self-assemble (Fig. 3a) in small discoid-like particles (10-15 $\mathrm{nm}$ diameter). Most probably these have a spherical micelle-like shape in solution and then collapse upon deposition when the imaging in air is performed. For 
both compounds it is possible to observe some of these aggregates by dilution till to a $10^{-6} \mathrm{M}$ concentration.

\section{[Insert Figure 3]}

Dynamic Light Scattering (DLS) experiments on the same $5 \times 10^{-4} \mathrm{M}$ solution of $\mathbf{2 b}$ support the presence of small sized aggregates (3-5 $\mathrm{nm}$ diameter), [31] which do not grow in the monitored time range of $24 \mathrm{~h}$ (Fig. $3 \mathrm{~b}$ ). The tendency of $\mathbf{2 a}$ and $\mathbf{2 b}$ to aggregate in water was rather surprising to us, because the two macrocycles have short methyl chains at the lower rim and should be characterised by sufficient conformational freedom to prevent a sharp distinction between the lipophilic (methylated aromatic nuclei) and the hydrophobic (sugar moieties) region in the molecule. Previously, we actually observed that the tetrapropoxy-tetraglucosylthioureidocalix[4]arene gives selfassociation in water solution, but it is fixed in the cone conformation, [25] and Micali et al reported [28] on aggregation phenomena of octapropoxycalix[8]arene analogues functionalised with $\mathrm{N}$-acetylglucosylthioureido units. In both these examples the longer propyl alkyl chains at the lower rim enhance the lipophilicity of the macrocycles. ESIMS studies previously showed [25] that cone tetrapropoxy-glycocalixarenes are able to bind anionic species, with some preference for phosphate/phosphonate containing guests. Unfortunately, when we used the two calix[6]- and calix[8]arene derivatives $2 \mathbf{a}$ and $\mathbf{2 b}$ in analogous, host-guest recognition MS experiments, no signal relative to any host-anion complex was found in the spectra. This was probably due to the high cone voltages necessary to detect the corresponding molecular peaks of these large macrocycles. However, the ability of $\mathbf{2 a}$ and $\mathbf{2} \mathbf{b}$ to interact with phosphate anions is indicated by their behaviour in a phosphate buffer. In fact, in phosphate buffer solutions, the AFM images relative to octamer $\mathbf{2 b}$ and hexamer $\mathbf{2 a}$ show the presence of 
aggregates which progressively and rapidly increase their size (Fig. 4). For example, in the case of $\mathbf{2} \mathbf{b}$, the aggregates appear larger (Fig. 4a) than in pure water after few minutes, then become $c a 100 \mathrm{~nm}$ sized after $90 \mathrm{~min}$ (Fig. 4b), and reach a diameter of 200-300 $\mathrm{nm}$ in $24 \mathrm{~h}$, with the simultaneous disappearance of the smaller aggregates (Fig. 4c). Higher concentrations of buffer and calixarene seem to speed up the rate of formation of these larger aggregates (Fig. 4d) whose solubility is evidently ensured by the presence of the charged phosphate anions included within the micelles. The particle stability, however, does not appear very high since sonication or simple stirring of the solution determine their dissociation in several small aggregates (Fig. 4e). A completely similar behaviour is observed in the case of $\mathbf{2 a}$ (e.g. see Fig. 4f). Upon standing for days a slow precipitation for both glucocalixarenes is observed also in these conditions.

\section{[Insert Figure 4]}

DLS experiments (Fig. 5) performed on a $5 \times 10^{-4} \mathrm{M}$ solution of $\mathbf{2 b}$ in $0.5 \mathrm{M}$ phosphate buffer $(\mathrm{pH} 7)$ show the same rapid formation and growth of the aggregates. Although the aggregate diameter estimated by this technique after 90 min from the dissolution of the calixarene in the buffer results slightly larger than that measured by AFM, these DLS experiments confirm the phenomenon and its trend.

\section{[Insert Figure 5]}

Other anions such as chloride, sulfate and nitrate do not cause similar effects, suggesting a peculiar interaction of these glucoclusters with the phosphate anion. For 
this reason, we also studied by AFM [32,33] the possible interaction between our glycoclusters and DNA. The images relative to mixtures of a $0.5 \mathrm{nM}$ plasmid DNA with $10^{-4} \mathrm{M}$ glucocalixarenes 2, registered after different, increasing incubation times, indicate that a binding between the two species occurs. The DNA filaments deposited on mica appear in the extended shape typical for supercoiled plasmids, while, in the presence of the glucocalixarene, aggregates of the multivalent ligand result located on the DNA plectonemes which, at the same time, evidence a higher constrain. However, we did not observe dramatic aggregation phenomena of DNA, changes in its folding or filament condensation [34,35] which otherwise could suggest the use of these derivatives as synthetic gene delivery systems [36-41]. In this respect the two glucoclusters $\mathbf{2 a}$ and $\mathbf{2 b}$ behave quite differently from the glycoresorcarenes reported by Aoyama and coworkers, which are able to condense DNA filaments and give cell transfection [42-44]. This quite different behaviour, could originate from the higher lipophilicity and/or the higher number of monosaccharide units at the upper rim of the resorcarenes compared to glucocluster 2 [43].

Although Concanavalin A (ConA) is selective for the $\alpha$ anomer of natural mannosides and glucosides, the discrimination ability between the two anomers can be strongly affected by the group linked at the anomeric position of the sugar, [45] as previously observed for glycosylthioureido cyclodextrins. [46] Therefore, we investigated the ability of our $\beta$-glucocalixarenes $\mathbf{2 a}$ and $\mathbf{2 b}$ to bind this lectin. Turbidimetric studies were performed using the glucoclusters at $5 \times 10^{-5} \mathrm{M}$. In the presence of ConA $\mathrm{ca} 10^{-5} \mathrm{M}$, both compounds are able to agglutinate the lectin (Fig. 6) with the formation of a suspension which determines an increase in the absorbance of the solution and which is not detectable when another lectin like peanut agglutinin, selective for galactose, is used 
(results not shown). Surprisingly and for reasons at the moment not completely clear, the efficiency of the octamer $\mathbf{2} \mathbf{b}$ looks considerably higher than that of the hexamer $\mathbf{2 a}$.

\section{[Insert Figure 6]}

The agglutination of ConA in presence of $\mathbf{2} \mathbf{b}$ was also followed by AFM as reported in Fig. 8. Images of a $c a 10^{-8} \mathrm{M}$ solution of ConA show the mica covered by many monomers of the lectin and some of its dimeric and tetrameric aggregates (Fig. 7a), while the mixture of $\mathbf{2 b}\left(10^{-4} \mathrm{M}\right)$ and lectin $\left(\mathrm{ca} 10^{-8} \mathrm{M}\right)$ shows, over time (Figs. $7 \mathrm{~b}$ and $7 \mathrm{c})$, the increase of the aggregate size and the simultaneous disappearance of the monomeric lectin which is progressively agglutinated.

\section{[Insert Figure 7]}

All together, the results obtained in this study allow to draw a more accurate picture of the aggregation properties by the multivalent glucoclusters $\mathbf{2 a}$ and $\mathbf{2 b}$ (Fig. 8). The ligands first aggregate in small particles (3-10 nm large) and these high valency species then interact with ConA giving agglutination with the formation of large supramolecular entities which progressively evolve toward precipitation because of the wide lectin cross-linking. The phosphate buffer also gives rise to the formation of large aggregates but, due to the fact that the alkyl chains at the calixarene lower rim are very short $\left(-\mathrm{CH}_{3}\right)$ and the macrocycles are conformationally mobile, these particles formed in the presence of phosphate buffer are not very stable in solution and a rather dynamic process exists which can be strongly affected by external factors. This makes the systems $\mathbf{2 a}$ and $\mathbf{2 b}$ 
different from other more lipophilic glycoclusters reported by others which give more robust aggregates [28,42].

\section{[Insert Figure 8]}

\section{Experimental procedures}

All moisture sensitive reactions were carried out under nitrogen atmosphere. All dry solvents were prepared according to standard procedures and stored over molecular sieves. Melting points were determined on an Electrothermal apparatus in capillaries sealed under nitrogen. ${ }^{1} \mathrm{H}$ and ${ }^{13} \mathrm{C}$ NMR spectra (300 and $75 \mathrm{MHz}$, respectively) were recorded on a Bruker AV300 spectrometer (partially deuterated solvents were used as internal standards). Mass spectra were recorded in ESI mode on a single quadrupole Micromass ZMD instrument (capillary voltage $=3 \mathrm{KV}$, cone voltage $=30-160 \mathrm{~V}$, extractor voltage $=3 \mathrm{~V}$, source block temperature $=80^{\circ} \mathrm{C}$, desolvation temperature $=$ $150{ }^{\circ} \mathrm{C}$, cone and desolvation gas $\left(\mathrm{N}_{2}\right)$ flow-rates $=1.6$ and $81 / \mathrm{min}$, respectively). TLC were performed on silica gel Merck $60 \mathrm{~F}_{254}$, and flash chromatography using 32-63 $\mu \mathrm{m}$, $60 \AA$ Merk silica gel. 5,11,17,23,29,35-Hexaamino-37,38,39,40,41,42hexamethoxycalix[6]arene and $\quad$ and $11,17,23,29,35,41,47$-octaamino49,50,51,52,53,54,55,56-octamethoxycalix[8]arene octahydrochloride were synthesised according to the literature procedures [30]. Concanavalin A was purchased from SigmaAldrich 
AFM sample preparation and imaging. Calixarene samples were prepared by diluting the compound to the desired concentration with milliQ water or with buffer or with the salt solution whose effects were under investigation. DNA samples were prepared by diluting the plasmid DNA to a final concentration of $0.5 \mathrm{nM}$ in deposition buffer (4 $\mathrm{mM}$ Hepes, $10 \mathrm{mM} \mathrm{NaCl}, 2 \mathrm{mM} \mathrm{MgCl} 2, \mathrm{pH}$ 7.4) either in the presence or absence of calixarenes. ConA samples were prepared by diluting the lectin to the concentration of ca $10^{-8} \mathrm{M}$ with milliQ water either in the presence or absence of calixarene. All the solutions studied were incubated for a defined time at room temperature, then a $20 \mu \mathrm{l}$ droplet was deposited onto freshly-cleaved ruby mica (Ted Pella, Redding, CA) for one minute. The mica disk was then rinsed with milliQ water and dried with a weak stream of nitrogen. AFM imaging was performed in air on the dried sample with a Nanoscope IIIA Microscope (Digital Instruments Inc.) operating in tapping mode. Commercial diving board silicon cantilevers (NSC-15 Micromash Corp.) were used. Images of $512 \times 512$ pixels were collected with a scan size of $2 \mu \mathrm{m}$ at a scan, rate of 3-4 lines per second and were flattened after recording using Nanoscope software.

Turbidimetric Analysis. $300 \mu \mathrm{l}$ of an aqueous solution $10^{-4} \mathrm{M}$ of glucocalix[n]arene were quickly mixed with $300 \mu \mathrm{l}$ of lectin aqueous solution $(0.5 \mathrm{mg} / \mathrm{ml})$. The turbidity change of the solution was monitored by reading the absorbance at $350 \mathrm{~nm}$ at regular time intervals until no noticeable changes could be observed, using a Perkin Elmer UVVis Lambda BIO 20 spectrophotometer. The sample cell was thermostated by a Peltier device at $25{ }^{\circ} \mathrm{C}$. All experiments were performed in triplicate. 
DLS analysis. Calixarene solutions in milliQ water or phosphate buffer $0.5 \mathrm{M}(\mathrm{pH} 7)$ were analyzed by using a Brookhaven ZetaPALS instrument. Measurements were performed at $25^{\circ} \mathrm{C}$, collecting scattered light at $90^{\circ}$ for $8 \mathrm{~min}$.

Synthesis of (tetraacetylglucosyl)thioureido calix[n]arenes. Aminocalixarene and tetraacetyl- $\beta$-glucosylisothiocyanate (1.5 equiv. for each $\mathrm{NH}_{2}$ group) are reacted in $\mathrm{CH}_{2} \mathrm{Cl}_{2}$ solution at room temperature for $24 \mathrm{~h}$ in the presence of $\mathrm{NEt}_{3}$ (1 equiv. for each $\mathrm{NH}_{2}$ group). The reaction is quenched by evaporation of the organic solvent at the rotary evaporator.

\section{5,11,17,23,29,35-Hexakis[(2,3,4,6-tetra-O-acetyl- $\beta$-D-glucopyranosyl)thioureido]-} 37,38,39,40,41,42-hexamethoxycalix[6]arene (1a). The compound is obtained by purification of the crude by flash column chromatography on silica gel (eluent: from hexane/AcOEt 3/2, v/v to hexane/AcOEt/MeOH 3/2/1, v/v/v). Yield: 60\%; M.p.: 194$195{ }^{\circ} \mathrm{C} .{ }^{1} \mathrm{H}$ NMR (300 MHz, DMSO-d 6 ): $\delta 9.66$ (bs, 6H, ArNH), 7.93 (bs, 6H, CHNHCS), 7.14 (s, 12H, ArH), 5.87 (bs, 6H, H1), 5.35 (t, 6H, J = 9.3 Hz, H3), 4.95 (m, 12H, H2, H4), 4.18 (bs, 6H, H6), 3.97 (bs, 12H, H5, H6'), 3.84 (s, 12H, ArCH $\mathrm{Ar}_{2}$ ), 3.20 (s, $\left.18 \mathrm{H}, \mathrm{OCH}_{3}\right), 1.96\left(\mathrm{~m}, 72 \mathrm{H}, \mathrm{CH}_{3} \mathrm{CO}\right) ;{ }^{13} \mathrm{C} \mathrm{NMR}\left(75 \mathrm{MHz}, \mathrm{CDCl}_{3}\right): \delta 181.7$ (s, CS), 170.9, 170.6, 169.7, 169.5 (CO), 155.6, 135.6, 135.1, 126.1, 124.9 (Ar), 86.3 (C1), 73.4, 72.7, 70.4, 68.1, 61.9 (C2-C6), $60.7\left(\mathrm{OCH}_{3}\right), 31.1\left(\mathrm{ArCH} \mathrm{H}_{2} \mathrm{Ar}\right), 20.9,20.7,20.5,20.3$ $\left(\mathrm{CH}_{3} \mathrm{CO}\right)$; ESI-MS: $\mathrm{m} / z$ 1595.9 [100\%, $\left.(\mathrm{M}+2 \mathrm{Na})^{2+}\right], 1071.6\left[75 \%,(\mathrm{M}+3 \mathrm{Na})^{3+}\right]$.

\section{$5,11,17,23,29,35,41,47-O c t a k i s[(2,3,4,6$-tetra-O-acetyl- $\beta$-D-}

glucopyranosyl)thioureido]-49,50,51,52,53,54,55,56-octamethoxycalix[8]arene (1b). 
The compound is obtained by crystallization from methanol while analytically pure samples by flash column chromatography on silica gel (eluent: hexane/AcOEt/MeOH 2.5/2.5/1, v/v/v). Yield: 72\%. M.p.: 179-182 ${ }^{\circ} \mathrm{C} .{ }^{1} \mathrm{H}$ NMR (300 MHz, $\left.\mathrm{CD}_{3} \mathrm{OD}, 343 \mathrm{~K}\right)$ : $\delta 6.96(\mathrm{~s}, 16 \mathrm{H}, \mathrm{ArH}), 5.89(\mathrm{~d}, 8 \mathrm{H}, J=9 \mathrm{~Hz}, \mathrm{H} 1), 5.35(\mathrm{dd}, 8 \mathrm{H}, J=9.6,9.3 \mathrm{~Hz}, \mathrm{H} 3)$, 5.02 (bs, 16H, H-2, H-4), 4.27 (dd, 8H, $J=8.1,3.9 \mathrm{~Hz}, \mathrm{H} 6$ ), 4.09 (dd, 8H, $J=8.1,2.4$ Hz, H6'), 4.02 (s, 16H, ArCH ${ }_{2} \mathrm{Ar}$ ), 3.96 (bs, 8H, H5), 3.51 (s, 24H, OCH OC $_{3} 1.99$ (m, 96H, $\left.\mathrm{CH}_{3} \mathrm{CO}\right) ;{ }^{13} \mathrm{C}$ NMR (75 MHz, $\left.\mathrm{CD}_{3} \mathrm{OD}\right): \delta 181.7$ (CS), 170.8, 170.5, 169.8, 169.6 (CO), 155.2, 135.1, 131.6, 125.8 (Ar), 82.7 (C1), 73.5, 73.0, 70.5, 68.2, 61.6 (C1-C6), $60.9\left(\mathrm{OCH}_{3}\right), 29.8\left(\mathrm{ArCH} \mathrm{H}_{2} \mathrm{Ar}\right), 20.4\left(\mathrm{CH}_{3} \mathrm{CO}\right)$. ESI-MS: $m / z 2120.3\left[20 \%,(\mathrm{M}+2 \mathrm{Na})^{2+}\right]$, $1421.2\left[30 \%,(\mathrm{M}+3 \mathrm{Na})^{3+}\right]$.

\section{General procedure for the deprotection of glucocalixarenes 1 from acetyl groups.}

The protected glucocalixarene $\mathbf{1}$ is suspended in methanol and a solution in the same solvent of $\mathrm{NaOMe}$ is added till $\mathrm{pH}=9$. After $30 \mathrm{~min}$ the reaction is quenched by neutralization with Amberlite IR-120 $\left(\mathrm{H}^{+}\right)$, then resin beads are filtered off and the desired product is recovered pure by evaporation to dryness of the organic solvent.

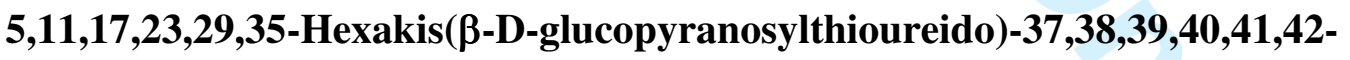

hexamethoxycalix[6]arene (2a). Yield: 90\%; ${ }^{1} \mathrm{H}$ NMR (300 MHz, DMSO- $\left.d_{6}, 353 \mathrm{~K}\right)$ : $\delta 9.36$ (bs, 6H, ArNH), 7.76 (bs, 6H, NH), 7.2 (s, 12H, ArH), 5.24 (bs, 6H, H1), 4.73 (bs, 24H, OH), 3.86 (s, 12H, ArCH $\left.H_{2} \mathrm{Ar}\right), 3.67$ (bd, 6H, $\left.J=11.1 \mathrm{~Hz}, \mathrm{H} 6\right), 3.49$ (bd, 6H, $J$ = 11.6 Hz, H6'), 3.33-2.95 (overlapped broad multiplets, 24H, H2, H3, H4, H5), 3.19 (s, $\left.18 \mathrm{H}, \mathrm{OCH}_{3}\right) ;{ }^{13} \mathrm{C} \mathrm{NMR}\left(75 \mathrm{MHz}, \mathrm{DMSO}-d_{6}\right): \delta 182.3$ (CS), 153.1, 134.8, 134.3, 126.0 
(Ar), $83.5(\mathrm{C} 1), 78.6,77.9,73.1,70.2,61.1(\mathrm{C} 2-\mathrm{C} 6), 60.5\left(\mathrm{OCH}_{3}\right), 30.9\left(\mathrm{ArCH}_{2} \mathrm{Ar}\right)$; ESI-MS: $m / z 2160.0\left[100 \%,(\mathrm{M}+\mathrm{Na})^{+}\right]$.

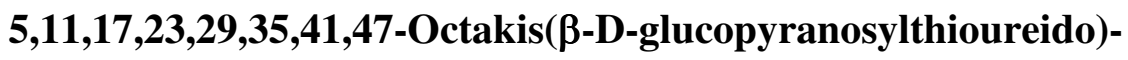

49,50,51,52,53,54,55,56-octamethoxycalix[8]arene (2b). If necessary, crystallization from methanol may result useful. Yield: $95 \% ;{ }^{1} \mathrm{H}$ NMR (300 MHz, $\left.\mathrm{D}_{2} \mathrm{O}, 363 \mathrm{~K}\right): \delta 6.95$ (s, 16H, ArH), 5.35 (bd, 8H, $J=8.4 \mathrm{~Hz}, \mathrm{H} 1), 3.88$ (s, 16H, ArCH $\left.\mathrm{Ar}_{2} \mathrm{Ar}\right), 3.76$ (bd, 8H, $J=$ 12.0 Hz, H6), 3.64 (bdd, 8H, $J=12.0,3.6 \mathrm{~Hz}, \mathrm{H6}$ '), 3.60-3.30 (overlapped broad multiplets, 32H, H2, H3, H4, H5), 3.37 (s, 24H, OCH $) ;{ }^{13} \mathrm{C}$ NMR (75 MHz, $\mathrm{D}_{2} \mathrm{O}, 363$ K): $\delta 183.0(\mathrm{CS}), 155.3,135.3,133.8$ and $126.9(\mathrm{Ar}) 84.5(\mathrm{C} 1), 77.9,77.3,73.1,70.2$, $61.6(\mathrm{C} 2-\mathrm{C} 6), 61.4\left(\mathrm{OCH}_{3}\right) 30.5\left(\mathrm{ArCH}_{2} \mathrm{Ar}\right)$; ESI-MS: $\mathrm{m} / \mathrm{z} 2873.0\left[10 \%,(\mathrm{M}+\mathrm{Na})^{+}\right], \mathrm{m} / \mathrm{z}$ $1448.1\left[100 \%,(\mathrm{M}+2 \mathrm{Na})^{2+}\right]$.

\section{Acknowledgments}

This work was partially supported by MUR (Ministero dell'Università e della Ricerca, Progetto PRIN 2006: Sistemi Supramolecolari per la Costruzione di Macchine Molecolari, Conversione dell'Energia, Sensing e Catalisi) and EU-COST Action D34. We thank prof. Gaetano Donofrio for providing plasmid DNA and CIM (Centro Interdipartimentale Misure) of the University of Parma for NMR and AFM facilities.

\section{References}

[1] Varki, A. Glycobiology 1993, 3, 97-130.

[2] Carbohydrates in Chemistry and Biology; Ernst, B., Hart, G. W., Sinaÿ, P., Eds.; Wiley-VCH: Weinheim, 2000; Vol. 4, pp. 535-1064.

[3] Bertozzi, C. R.; Kiessling, L. L. Science 2001, 291, 2357-2364. 
[4] Gabius, H. J.; Andre, S.; Kaltner, H.; Siebert, H. C. Biochim. Biophys. Acta 2002, 1572, 165-177.

[5] Gabius, H. J. Biochim. Biophys. Acta 2002, 1572, 163-164.

[6] Hakomori, S. Arch. Biochem. Biophys. 2004, 426, 173-181.

[7] Sharon, N. Biochim. Biophys. Acta, Gen. Subj. 2006, 1760, 527-537.

[8] Sharon, N. Biochemist 2006, 28, 13-17.

[9] Kiessling, L. L.; Young, T.; Mortell, K. H. Glycoscience 2001 , 2, 1817-1861.

[10] Kitov, P. I.; Bundle, D. R. J. Am. Chem. Soc. 2003, 125, 16271-16284.

[11] Zhang, Z. S.; Merritt, E. A.; Ahn, M.; Roach, C.; Hou, Z.; Verlinde, C. L. M. J.; Hol, W. G. J.; Fan, E. J. Am. Chem. Soc. 2002, 124, 12991-12998.

[12] Mellet, C. O.; Defaye, J.; Fernandez, J. M. G. Chem. Eur. J. 2002, 8, 1982-1990.

[13] Wittmann, V. Highlights Bioorg. Chem. 2004 203-213.

[14] Pieters, R. J. Trends Glycosci. Glycotech. 2004, 16, 243-254.

[15] Gao, Y.; Eguchi, A.; Kakehi, K.; Lee, Y. C. Bioorg. Med. Chem. 2005, 13, 61516157.

[16] Dubber, M.; Sperling, O.; Lindhorst, T. K. Org. Biomol. Chem. 2006, 4, 39013912.

[17] Kim, J.; Ahn, Y.; Park, K. M.; Kim, Y.; Ko, Y. H.; Oh, D. Y.; Kim, K. Angew. Chem. Int. Ed. 2007, 46, 7393-7395.

[18] Gargano, J. M.; Ngo, T.; Kim, J. Y.; Acheson, D. W. K.; Lees, W. J. J. Am. Chem. Soc. 2001, 123, 12909-12910.

[19] Lee, Y. C.; Lee, R. T. Acc. Chem. Res. 1995, 28, 321-327.

[20] Fulton, D. A.; Elemento, E. M.; Aime, S.; Chaabane, L.; Botta, M.; Parker, D. Chem. Commun. 2006 1064-1066.

[21] Rojo, J.; Diaz, V.; de la Fuente, J. M.; Segura, I.; Barrientos, A. G.; Riese, H. H.; Bernade, A.; Penades, S. Chembiochem 2004, 5, 291-297.

[22] de la Fuente, J. M.; Penades, S. Biochim. Biophys. Acta, Gen. Subj. 2006, 1760, 636-651.

[23] Ojeda, R.; de Paz, J. L.; Barrientos, A. G.; Martin-Lomas, M.; Penades, S. Carbohydr. Res. 2007, 342, 448-459.

[24] Baldini, L.; Casnati, A.; Sansone, F.; Ungaro, R. Chem. Soc. Rev. 2007, 36, $254-$ 266.

[25] Sansone, F.; Chierici, E.; Casnati, A.; Ungaro, R. Org. Biomol. Chem. 2003, 1, 1802-1809.

[26] Arosio, D.; Fontanella, M.; Baldini, L.; Mauri, L.; Bernardi, A.; Casnati, A.; Sansone, F.; Ungaro, R. J. Am. Chem. Soc. 2005, 127, 3660-3661.

[27] Hayashida, O.; Mizuki, K.; Akagi, K.; Matsuo, A.; Kanamori, T.; Nakai, T.; Sando, S.; Aoyama, Y. J. Am. Chem. Soc. 2003, 125, 594-601. 
[28] Micali, N.; Villari, V.; Consoli, G. M. L.; Cunsolo, F.; Geraci, C. Phys. Rev. E 2006, 73.

[29] Storr, T.; Merkel, M.; Song-Zhao, G. X.; Scott, L. E.; Green, D. E.; Bowen, M. L.; Thompson, K. H.; Patrick, B. O.; Schugar, H. J.; Orvig, C. J. Am. Chem. Soc. 2007, 129, 7453-7463.

[30] Dudic, M.; Colombo, A.; Sansone, F.; Casnati, A.; Donofrio, G.; Ungaro, R. Tetrahedron 2004, 60, 11613-11618.

[31] Aggregates of similar size were also detected by DLS for analogous glycoresorcinarenes as the results of the self-assembly of ca. 6 macrocycles (see ref. 42).

[32] Volcke, C.; Pirotton, S.; Grandfils, Ch.; Humbert C.; Thiry, P. A.; Ydens, I.; Dubois, P.; Raes, M. J. Biotech 2006, 125, 11-21.

[33] Ceci, P.; Cellai, S.; Falvo, E.; Rivetti, C.; Rossi, G. L.; Chiancone, E. Nucleic Acids Res. 2004, 32, 5935-5944.

[34] Bloomfield, V. A. Curr. Opin. Struct. Biol. 1996, 6, 334-341.

[35] Sansone, F.; Dudic, M.; Donofrio, G.; Rivetti, C.; Baldini, L.; Casnati, A.; Cellai, S.; Ungaro, R. J. Am. Chem. Soc. 2006, 128, 14528-14536.

[36] Kirby, A. J.; Camilleri, P.; Engberts, J. B. F. N.; Feiters, M. C.; Nolte, R. J. M.; Soderman, O.; Bergsma, M.; Bell, P. C.; Fielden, M. L.; Rodriguez, C. L. G.; Guedat, P.; Kremer, A.; McGregor, C.; Perrin, C.; Ronsin, G.; van Eijk, M. C. P. Angew. Chem. Int. Ed. 2003, 42, 1448-1457.

[37] Wasungu, L.; Hoekstra, D. J. Controlled Release 2006, 116, 255-264.

[38] Pietersz, G. A.; Tang, C. K.; Apostolopoulos, V. Mini-Rev. Med. Chem. 2006, 6, 1285-1298.

[39] Kostarelos, K.; Miller, A. D. Chem. Soc. Rev. 2005, 34, 970-994.

[40] Tiera, M. J.; Winnik, F. M.; Fernandes, J. C. Curr. Gene Ther. 2006, 6, 59-71.

[41] Li, S. D.; Huang, L. Gene Ther. 2006, 13, 1313-1319.

[42] Aoyama, Y. Chem. Eur. J. 2004, 10, 588-593.

[43] Aoyama, Y. Trends Glycosci. Glycotech. 2005, 17, 39-47.

[44] Horiuchi, S.; Aoyama, Y. J. Controlled Release 2006, 116, 107-114.

[45] Lis, H.; Sharon, N. Chem. Rev. 1998, 98, 637-674.

[46] Baussanne, I.; Benito, J. M.; Mellet, C. O.; Fernandez, J. M. G.; Defaye, J. ChemBioChem 2001, 2, 777-783. 


\section{Captions to Figures}

Figure 1. ${ }^{1} \mathrm{H}$ NMR spectra (300 MHz) of compound $\mathbf{1 b}$ in a) $\mathrm{CDCl}_{3}$ at $298 \mathrm{~K}$, b) $\mathrm{CD}_{3} \mathrm{OD}$ at $298 \mathrm{~K}, \mathrm{c}) \mathrm{CD}_{3} \mathrm{OD}$ at $343 \mathrm{~K}$.

Figure 2. ${ }^{1} \mathrm{H}$ NMR of $\mathbf{2 b} 10^{-3} \mathrm{M}$ in $\mathrm{D}_{2} \mathrm{O}$ at a) $298 \mathrm{~K}$ and b) $363 \mathrm{~K}$.

Figure 3. a) AFM image $(2 \times 2 \mu \mathrm{m})$ in tapping mode of a $5 \times 10^{-4} \mathrm{M}$ solution of $\mathbf{2 b}$ and $\left.\mathbf{b}\right)$ relative abundance $v s$ diameter size of its aggregates detected by DLS.

Figure 4. AFM images $(2 \times 2 \mu \mathrm{m})$ on mica of a $10^{-4} \mathrm{M}$ solution of $\mathbf{2 b}$ in phosphate buffer $0.1 \mathrm{M} \mathrm{(pH} \mathrm{7)} \mathrm{after} \mathrm{a)} 8 \mathrm{~min}$, b) $90 \mathrm{~min}$ and c) $20 \mathrm{~h}$ from the preparation of the solution; d) of a $5 \times 10^{-4} \mathrm{M}$ solution of $\mathbf{2 b}$ in phosphate buffer $0.5 \mathrm{M}(\mathrm{pH} 7)$ after 90 min from the preparation; e) the same of d) but after sonication for $1 \mathrm{~h}$ before deposition on mica; f) of a $5 \times 10^{-5} \mathrm{M}$ solution of $2 \mathbf{a}$ in phosphate buffer $0.1 \mathrm{M}(\mathrm{pH}$ 7) after $24 \mathrm{~h}$ from the preparation.

Figure 5. Relative abundance $v s$ diameter size of the aggregates detected by DLS for a $5 \times 10^{-4} \mathrm{M}$ solution of $\mathbf{2 b}$ in phosphate buffer $0.5 \mathrm{M}$ ( $\mathrm{pH} 7$ ) after $5 \mathrm{~min}$ (top), 30 min (middle) and $18 \mathrm{~h}$ (bottom).

Figure 6. Optical density values $(350 \mathrm{~nm})$ vs time relative to a solution of $2 \mathbf{a}(O)$ and its mixture with $\operatorname{ConA}(\triangle)$ and a solution of $\mathbf{2 b}(\mathbf{\bullet})$ and its mixture with ConA $(\mathbf{\square})$.

Figure 7. AFM images $(2 \times 2 \mu \mathrm{m})$ on mica of a) a $c a 10^{-8} \mathrm{M}$ aqueous solution of Con $\mathrm{A}$, b) a mixture of $2 \mathbf{b}\left(10^{-4} \mathrm{M}\right)$ and $\operatorname{ConA}\left(c a 10^{-8} \mathrm{M}\right)$ after $15 \mathrm{~min}$ and c) after $3 \mathrm{~h}$ of incubation.

Fig. 8. Schematic representation of the aggregation processes involving glucocalixarenes $\mathbf{2}$ and ConA or phosphate anions. 


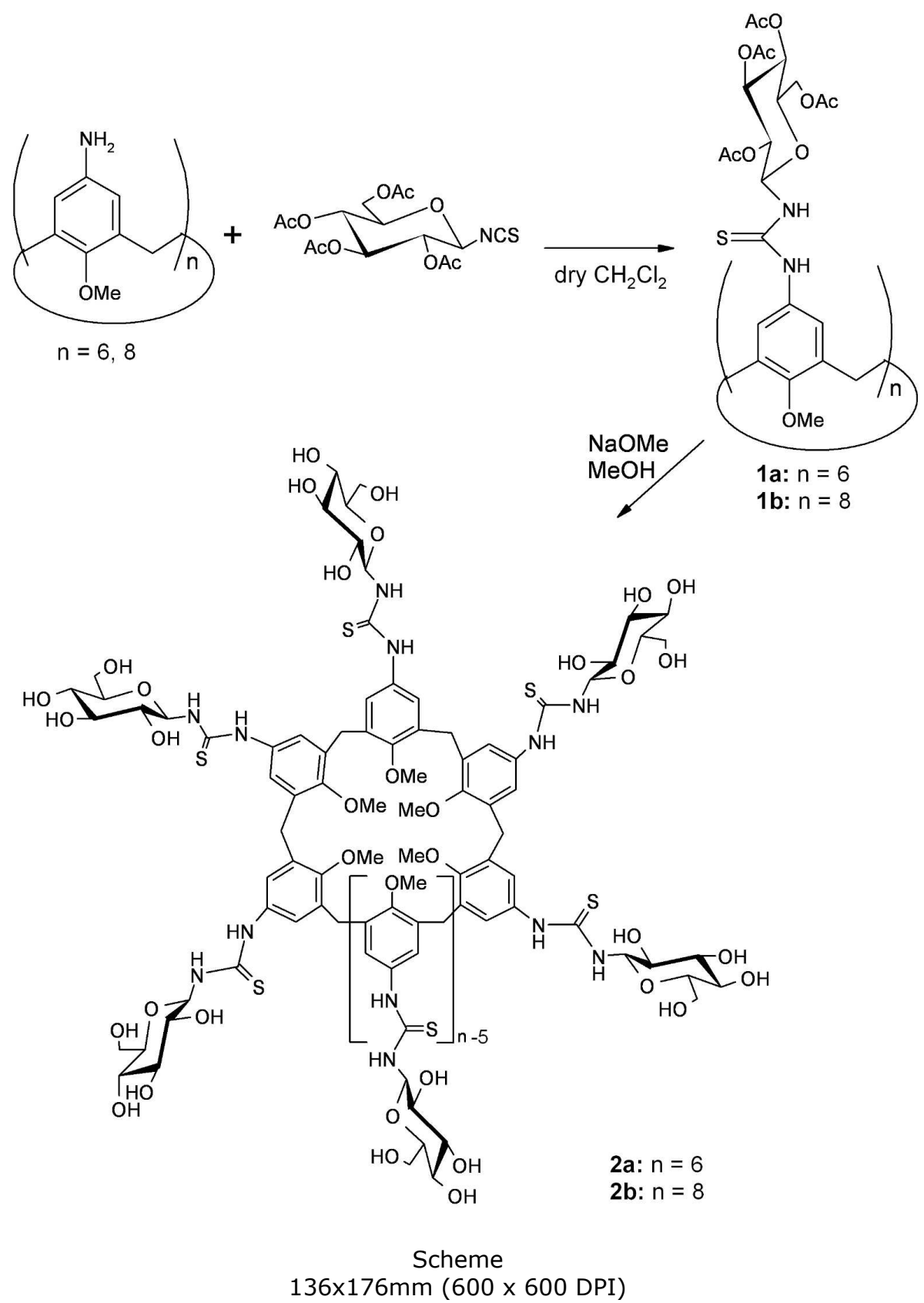




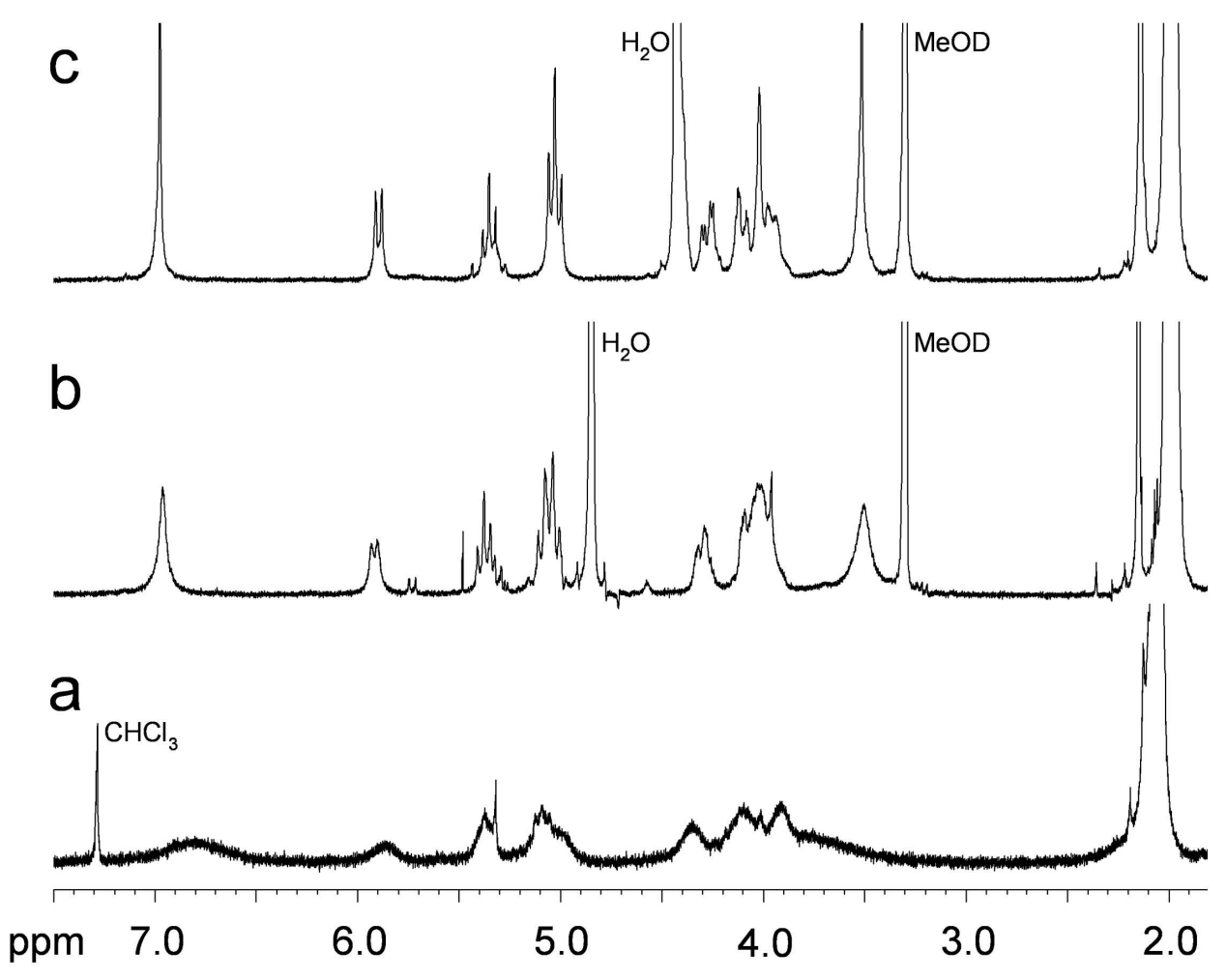

Figure 1

$99 \times 77 \mathrm{~mm}(600 \times 600 \mathrm{DPI})$ 
1

2

3

4

5

6

7

8

10

11

12

13

14

15

16

17

18

19

20

21

22

23

24

25

26

27

28

29

30

31

32

33

34

35

36

37

38

39

40

41

42

43

44

45

46

47

48

49

50

51

52

53

54

55

56

57

58

59

60

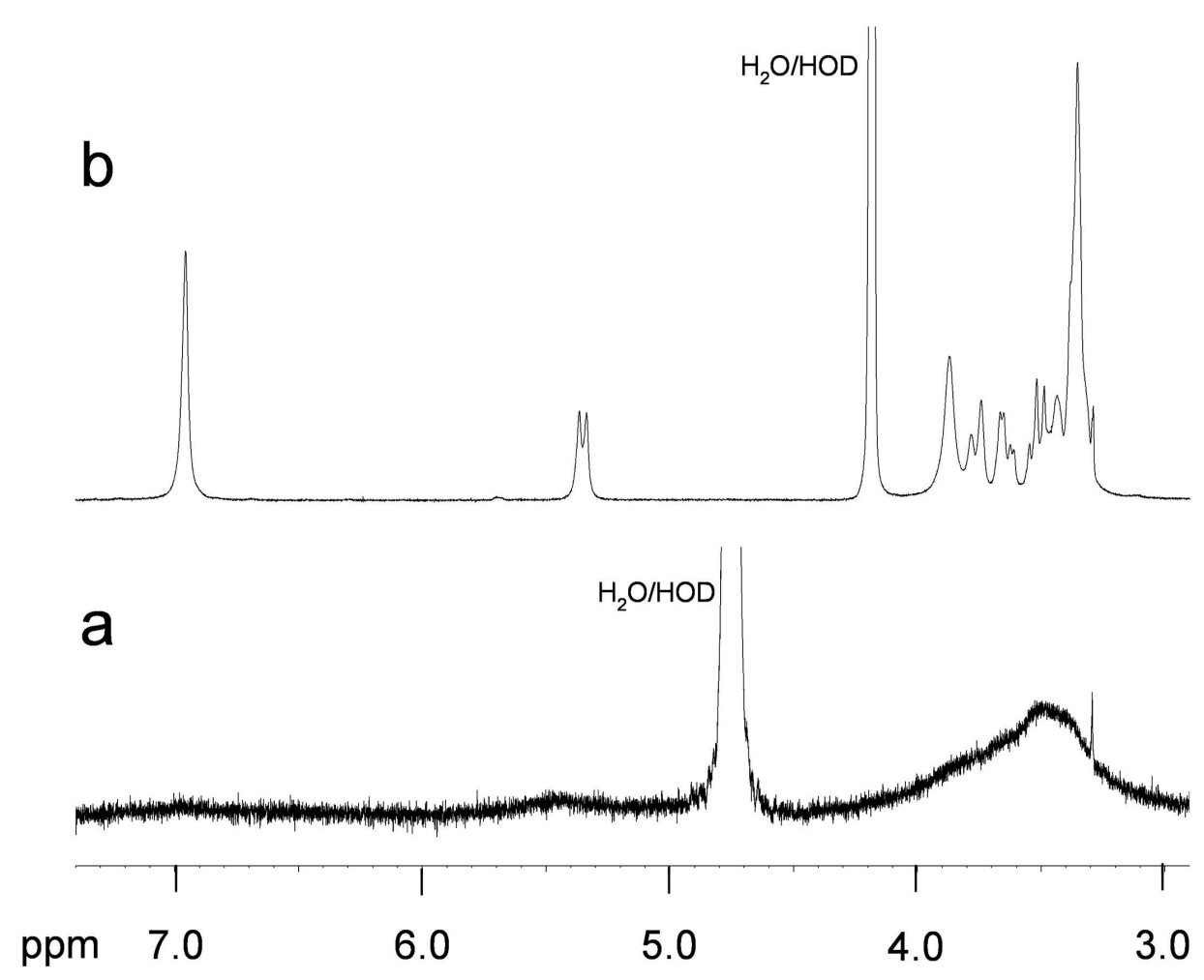

Figure 2

$98 \times 75 \mathrm{~mm}(600 \times 600$ DPI $)$ 

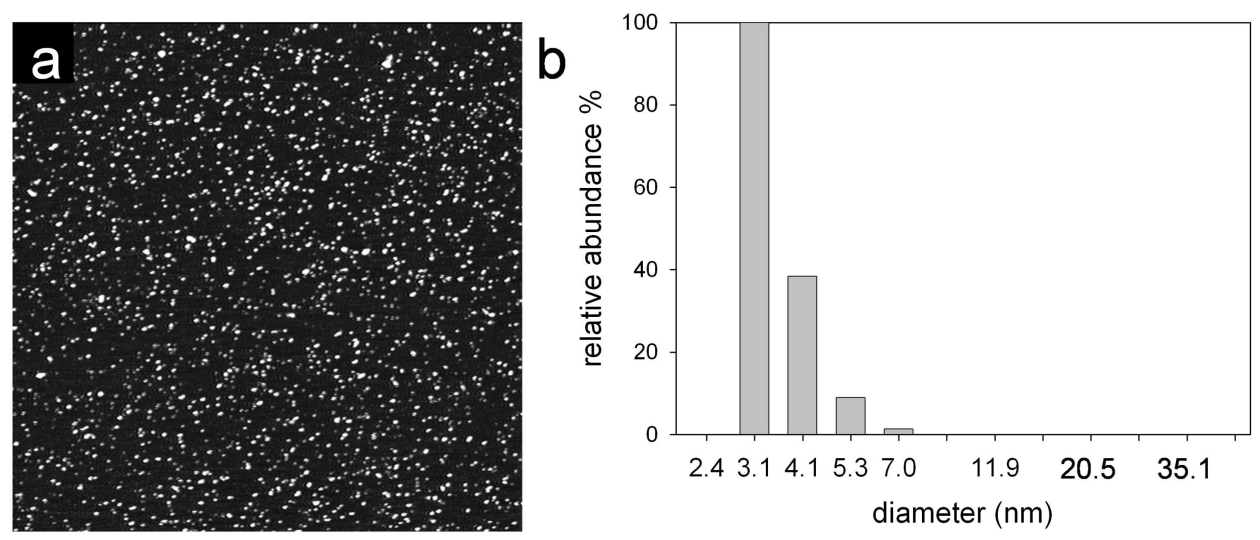

Figure 3

$127 \times 52 \mathrm{~mm}(600 \times 600$ DPI $)$

25

26

27

28

29

30

31

32

33

34

35

36

37

38

39

40

41

42

43

44

45

46

47

48

49

50

51

52

53

54

55

56

57

58

59

60

URL: http:/mc.manuscriptcentral.com/tandf/gsch Email: suprachem@mail.cm.utexas.edu 

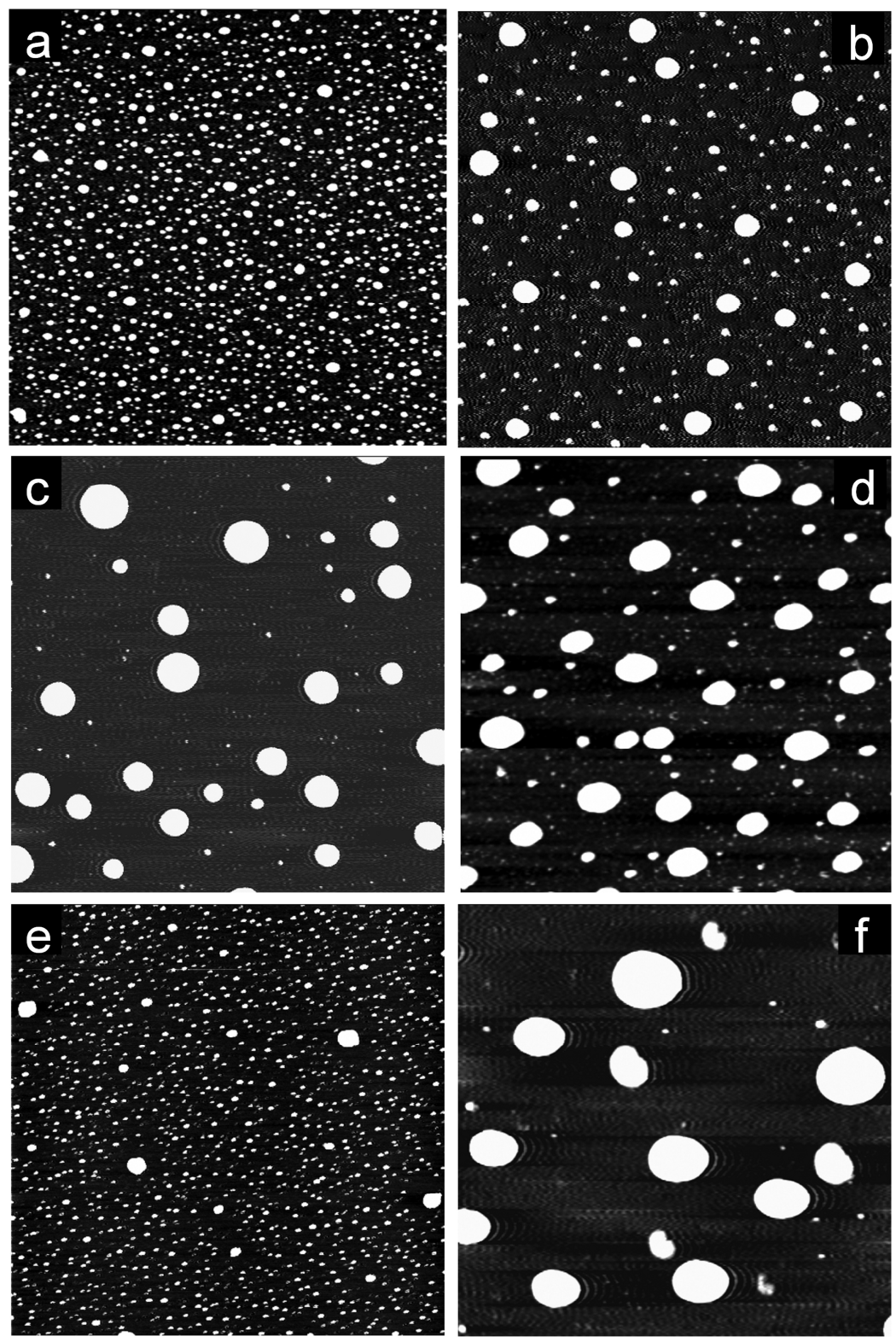

Figure 4

$101 \times 153 \mathrm{~mm}(600 \times 600$ DPI $)$ 

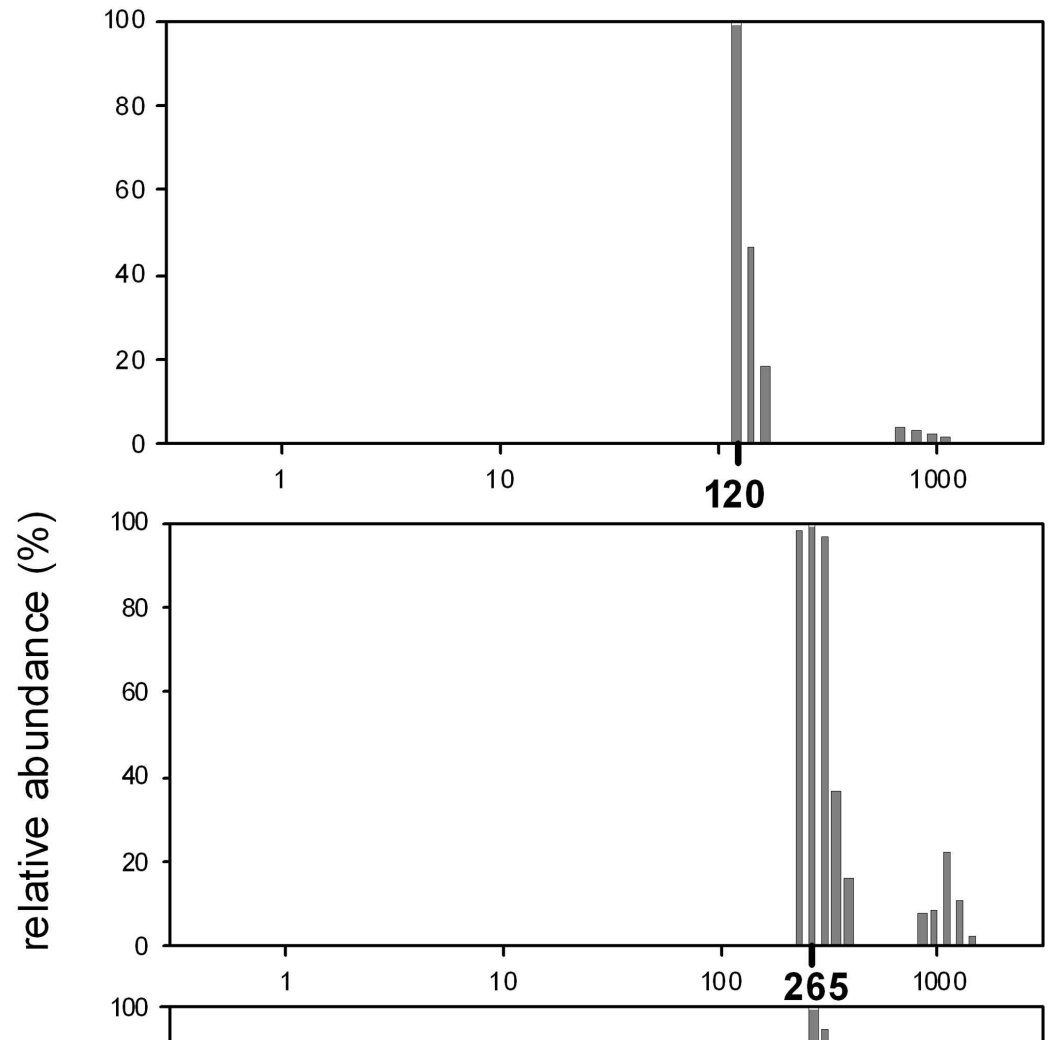


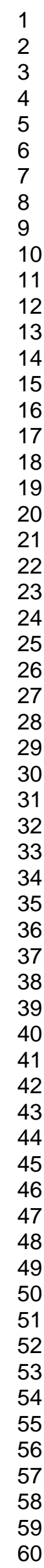

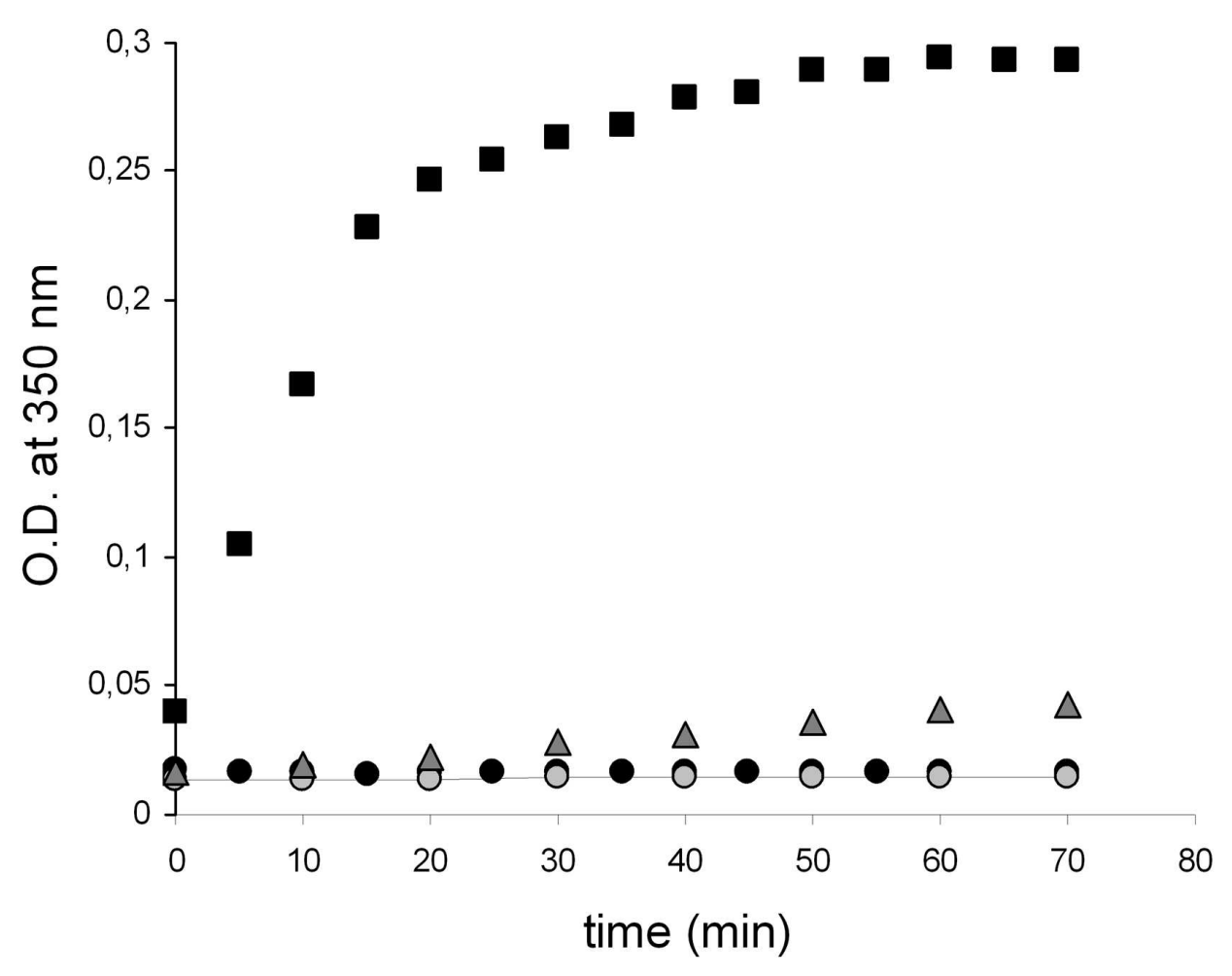

Figure 6

$75 \times 59 \mathrm{~mm}(600 \times 600 \mathrm{DPI})$ 


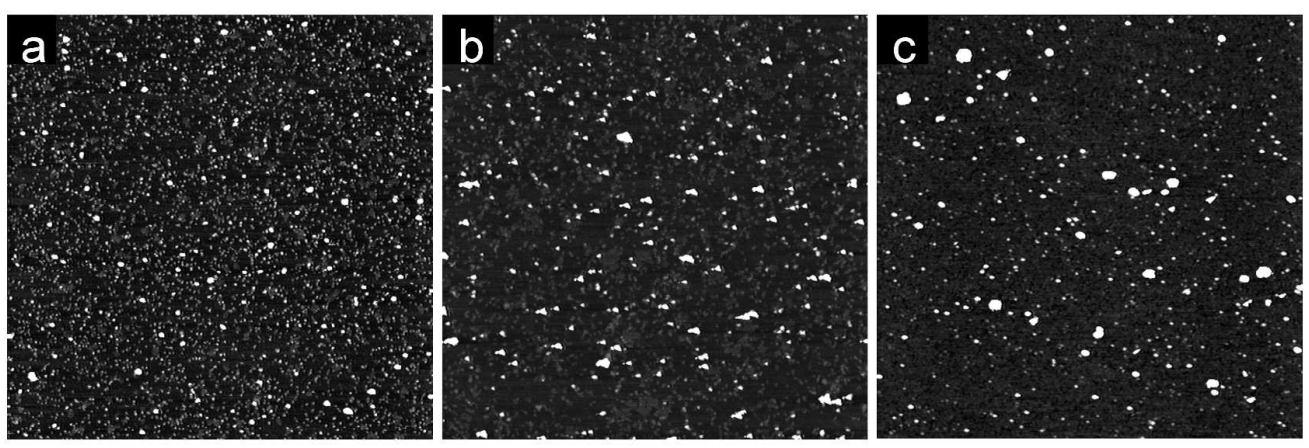

Figure 7

$141 \times 47 \mathrm{~mm}(600 \times 600 \mathrm{DPI})$ 
Figure 8

$227 \times 83 \mathrm{~mm}(600 \times 600 \mathrm{DPI})$ 


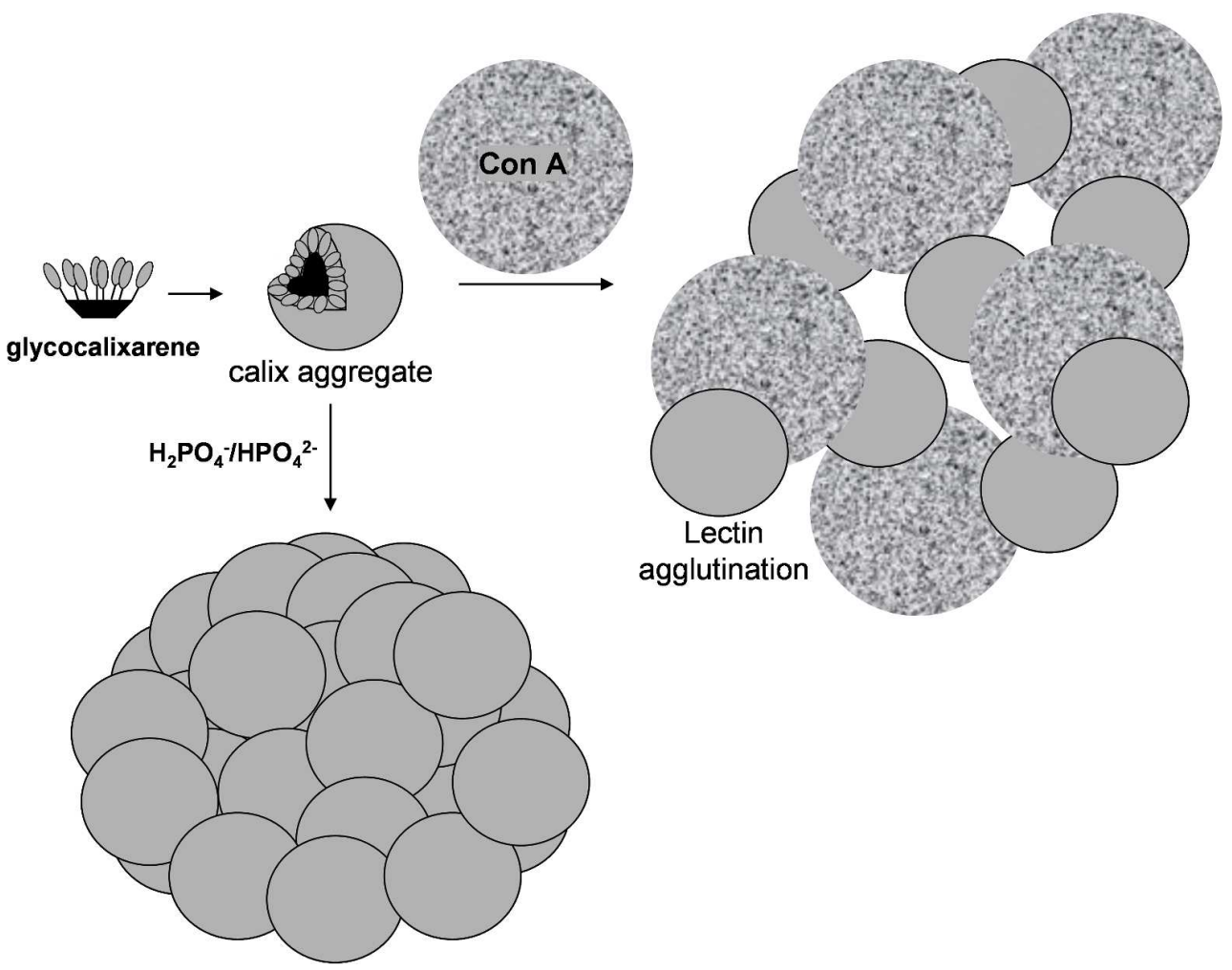

Picture for the graphical abstract $204 \times 156 \mathrm{~mm}(600 \times 600$ DPI $)$ 